\title{
JUAL BELI DENGAN SISTEM HUTANG DI PASAR TRADISIONAL DALAM PERSPEKTIF HUKUM PERDATA
}

\author{
H. Syamsul Munir*
}

\begin{abstract}
Debt trading in traditional markets with a nominal value of Rp. 1,000,000 (one million rupiah) down is usually done by recording under the hand. The seller emphasizes the element of trust rather than the element of legal proof. The process of buying and selling is fast, simple and if it is implemented with accounts receivable debt that is done simply, if the debt is stalled, intensive collection is carried out and the seller will receive it if paid in installments or in installments. In the process of payment the merchant does not provide interest expense or operating expenses due to the collection. If there is a debt dispute, the settlement is carried out in a family manner without involving law enforcement. Bad debt is certainly a calculation for traders who dare to pay off their merchandise. The factor of bad debt is usually not more than $20 \%$ of the total debt - the debt that must be paid by buyers with the debt system. Therefore the process runs in such a way and is considered natural. So the customary law factor that debt must be paid and the legal factor of trade that if you don't pay the debt will sin more debt for the parties than the legal proof factor.
\end{abstract}

* Dosen Fakultas Hukum Universitas Lumajang 


\section{Jual Beli di Pasar Tradisional}

Perjanjian jual beli di pasar tradisional pada segmen di bawah nominal Rp. 1.000.000 (satu juta rupiah) umumnya bila terjadi hutang piutang antara penjual dan pembeli hanya menggunakan standar sepakat, selanjutnya proses hutang piutang tersebut dicatat oleh pihak penjual yaitu pihak yang memberikan hutang dalam catatan buku biasa, sedangkan pihak yang berhutang cukup mengetahui tanpa memberikan tanda tangannya dalam buku catatan tersebut.

Proses yang seperti sudah umum terjadi antara pihak penjual perorangan dengan pihak pembeli perorangan. Obyek penjualan umumnya adalah obyek pracangan, pecah belah, palen, buah-buahan dan sayur-sayuran, makanan ringan, bahan-bahan makanan. Obyek penjualan ini dalam ukuran kuantitas tidak menggunakan partai besar / kuintal dan macam-macamnya tidak banyak, tetapi ukuran penjualannya biasanya menggunakan partai kecil atau kilogram dan macam-macam obyek penjualannya banyak.

Dengan demikian jual beli pada segmen pasar tradisional dan sifatnya perorangan, tidak melibatkan pihak penjual, agen besar ataupun distributir dari pabrik-pabrik tertentu yang sudah menggunakan administrasi yang tertib, melainkan jual beli perorangan yang cenderung menggunakan tempat penjualannya memakai bedak / petak / toko kecil ataupun menggunakan rombong penjualan yang biasanya luasnya antara $1 \times 2 \mathrm{~m}$ atau $2 \times 2 \mathrm{~m}$ atau $2 \times 3 \mathrm{~m}$ atau $3 \times 3 \mathrm{~m}$ atau $3 \times 4 \mathrm{~m}$.

Lokasi dan luas petak atau bedak berada didalam pasar ataupun pinggir pasar yang merupakan bagian dari pasar dan status tanah dan bangunannya adalah HGB (Gak Guna Bangunan).

\section{Unsur - unsur Pasal 1320 KUH Perdata}

Perjanjian jual beli yang terjadi di pasar tradusional dalam segmen di bawah Rp. 1.000.000 (satu juta rupiah) yang seperti itu bila ditinjau dari segi hukum perdata itu unsur yang dipenuhi adalah unsur konsensualisme. Unsur konsensual atau kesepakatan antara pihak penjual dan pihak pembeli sudah terpenuhi tentang barang dan harga khususnya, artinya pihak penjual dan pihak pembeli sudah tercapai persesuaian kehendak tentang barang yang dijual. Sudah barang tentu persesuaian kehendak 
tersebut sudah meliputi persesuaian tentang mutu atau kualitas barang dan kesesuaian tentang jumlah barang, sehingga keduanya mencapai kata sepakat dalam masalah barang yang menjadi obyek jual beli tersebut. Kesepakatan yang terjadi tersebut tidak dituangkan dalam bentuk tulisam melainkan kesepakatan tersebut dituangkan dalam bentuk lisan, artinya pihak penjual oke dan pihak pembeli juga sudah oke.

Persesuaian kehendak tersebut juga sudah meliputi persesuaian tentang harga yang harus dibayar, masalahnya bila harga yang harus dibayardilakukan dengan tunai tidak masalah melainkan sudah selesai proses terjadinya jual beli tersebut. Bila proses jual beli tersebut dengan hutang piutang, maka masalahnya menjadi lain. Proses hutang piutang yang terjadi akan dilakukan dengan pencatatan sejumlah barang yang dihutang. Pencatatan tanggal terjadinya proses jual beli dan kadang ditulis kapan hutang tersebut akan dibayar bahkan kadang hutang tersebut kapan harus dibayar tidak tertulis. Jadi hanya di tulis jumlah hutangnya saja.

Proses hutang piutang yang timbul akibat perjanjian jual beli tersebut sudah memenuhi azas konsensualisme sebagai dasar timbulnya perjanjian, menurut Prof. Subekti.

Unsur-unsur pokok (essentialia) perjanjian jual beli adalah barang dan harga (Subekti, 1985: 2). Ketika harga dari pembelian sejum lah barang tersebut pembayarannya ditangguhkan atau dengan sistem hutang maka perjanjian jual beli tersebut dilanjutkan dengan proses perjanjian hutang piutang, antara pembeli dan penjual.

Prof. Subekti melanjutkan bahwa:

Dengan hanya disebutkannya "sekapat" saja tanpa di tuntutnya suatu cara (formalitas) apapun, sepertinya tulisan pemberian tanda atau panjar dan lain sebagainya, dapat kita simpulkan bahwa bilamana sudah tercapai sekapat itu, maka sahlah sudah perjanjian itu atau mengikatlah perjanjian itu, atau berlakulah ia sebagai undangundang bagi bereka yang membuatnya (Subekti, 1985: 4).

Pada pasal 1320 Kitab Undang Undang Hukum Perdata disebutkan, bahwa syarat - syarat perjanjian adalah:

1. Sepakat

2. Kecakapan 
3. Hal tertentu

4. Sebab yang halal

Dengan demikian perjanjian tersebut sudah memenuhi syarat pasal 1320 (1) Kitab UU Hukum Perdata.

Sementara pada pasal 1458 Kitab UU Hukum Perdata berbunyi “ Jual beli itu dianggap telah terjadi diantara kedua belah pihak seketika setelah orang-orang ini mencapai sekapat tentang barang tersebut dan harganya, meskipun barang tersebut belum diserahkan mupun harganya belum dibayar.

Dengan demikian bila ditilik dari sisi hukum maka terjadinya jual beli dengan memakai azas konsensulisme saja, pada dasarnya sudah sah namun demikian bila didasarkan pada pasal 1320 Kitab UU Hukum Perdata, masih perlu dilaksanakan tentang kecakapan pada masing-masing penjual dan pembeli, tentang obyek menjadi jual beli dan tentang status obyek maupun status subyek dalam melakukan jual beli jual beli tidak boleh bertentangan dengan hukum. Adapun pembayarannya dilakukan dengan cara berhutang itu merupakan langkah berikutnya tentang tata cara hutang piutang, sedangkan jual belinya itu sendiri sudah terjadi dan sah menurut sisi hukum sebagaimana terdapat pada pasal 1338 (1) Kitab UU Hukum Perdata yang berbunyi:

Suatu perjanjian yang dibuat secara sah, mengikat sebagai Undang - Undang bagi para Pihak.

\section{Pasal 1338 (3) Kitab UU Hukum Perdata}

Setiap perjanjian harus dilaksanakan demgam itikad baik.

Jika jual beli sudah dinyatakan sah menurut pihak penjual dan pihak pembeli tentang obyek barang dan harga, maka saat penyerahan barang dan saat pembayaran haruslah juga dinyatakan diterima walaupun pembayaran dilakukan dengan sistem hutang. Jika pihak penjual menyatakan menerima dengan kondisi seperti itu, maka beralihlah pokok permasalahan dari jual beli ke hutang piutang.

Suharnoko dalam bukunya Hukum Perjanjian menyatakan:

Kehendak para Pihak yang diwujudkan dalam kesepakatan adalah meripakan dasar mengikat suatu perjanjian (Suharnoko, 2004:3). 
Menurut Herlien Budiono yang dikemukakan Sudikno Mertukusomo menegaskan bahwa ada 5 cara terjadinya persesuaian pernyataan kehendak yaitu dengan:

1. Bahasa yang sempurna dan tertulis.

2. Bahasa yang sempurna secara lesan.

3. Bahasa yang tidak sempurna, asal dapat dimengerti dan diterima oleh pihak lawan.

4. Bahasa isyarat, asal dapat dimengertikan diterima oleh pihak lawannya.

5. Diam atau membisa, asal dipahami atau diterima pihak lawan (Muhammad Syaifuddin, 2012:113)

Dengan demikian jual beli oleh para pihak tersebut duatas yang dilaksanakan tanpa tertulis menurut Suharnoko Syaifudin dinyatakan sah. Demikian pula pembayarannya yang dinyatakan dengan hutang juga dinyatakan sah juga. Sepanjang pihak penjual menyatakan menerima pernyataan hutang tersebut.

\section{Hutang Piutang dalam Proses Jual Beli}

Hutang piutang yang terjadi akibat terjadinya jual beli dengan azas konsesntus atau persesuaian kehendak antara penjual dan pembeli dengan pembayaran memakai sistem hutang yang pencatatannya dilakukan dengan sederhana, yaitu penjual mencatat hutang tersebut dalam sebuah buku atau lainnya dan pembayarannya pun tidak dipastikan secara jelas. Hanya memakai kebiasaan satu minggu, dua minggu atau satu bulan tergantung dengan kebiasaan sesuai dengan kesepakatan. Hal yang terjadi umumnya di pasar tradisional kesepakatan hutang piutang yang tidak dilakukan secara tertulis dan diketahui oleh minimal dua saksi. Pihak penjual mempunyai hitungan tersendiri tentang barangnya yang dijual dengan sistem hutang. Sudah barang tentu pihak penjual sudah memperhitungkan tentang rugi dan labanya, juga sudah memperhitungkan tentang resikonya bila hutang tersebut tidak dibayar.

Sudah barang tentu pihak penjual sudah mempelajari dengan sungguh-sungguh calon pembelinya yang pembayarannya memakai sistem hutang. Jadi tidak begitu saja secara menyeluruh memberi hutang pada seluruh calon pembelinya, bisa jadi faktor kepercayaan itu karena 
sudah mengenal lebih dahulu atau faktor kepercayaan itu timbul karena perhitungan tersendiri, yang mungkin bagi orang awam karena begitu pemahamannya. Namun demikian sejalan waktu faktor resiko yaitu sudah diperhitungkan dengan seksama, karena kalau tidak, bisa jadi pihak penjual ataupun pedagang tersebut sudah gulun tikar, dikarenakan banyak yang macet. Hal itu juga sering terjadi di pasar tradisional terhadap pedagang-pedagang yang kurang beruntung dikarenakan macetnya hutang-hutang yang ada dipelanggannya. Hal yang seperti ini sudah barang tentu dianggap faktor resiko bagi para pedagang dalam menjalankan obyek jual belinya.

Selanjutnya kita soroti praktek hutang piutang yang dilaksanakan tanpa bukti tanda tangan bahkan tanpa bukti saksi tersebut. Bila proses hutang piutang didasari dengan pasal 1320 KUH Perdatadalam ayat (1) sepakat mereka yang mengikatkan dirinya.

Kata sepakat sudah tentu diawali dengan persesuaian kehendak antara penjual dan pembeli tentang obyek barang yang dibeli dan sejumlah uang yang disepakati sebagai perantaranya. Selanjutnya dalam melihat ayat (2) tentang cakap, pihak pedagang kurang begitu mengerti secara teori apa yang dianggap cakap dalam perundag-undangan yang berlaku. Namun secara sederhana mereka memahami bahda sudah kawin, atau sudah tua, tidak muda dan tidak gila merupakan patokan sederhana bagi pedagang. Paling tidak mereka sudah mengetahui dalam praktek merealisasikan pasal $1320 \mathrm{KUH}$ Perdata tersebut. Untuk hal tertentu dan sebab yang halal, mereka mengetahuinya barang ini adalah barang milik saya, hasil kulakan / perbelajaan oleh saya, bukan barang hasil pencurian. Dengan demikian mereka menganggap barang tersebut adalah barang yang tidak melanggar undang-undang, dan tidak ada yang perlu ditakutkan untuk dijual belikan. Demikian pemikiran pedagang dalam merealisasikan pasal 132 KUH Perdata secara umum dengan cara pemikiran yang sederhana.

Untuk hutang itu terdiri ditulis secara sederhana tanpa ada tanda tangan, tanpa bukti saksi, dianggap mereka sudah cukup, mereka meletakkan faktor kepercayaan lebih tinggi, dari pada meletakkan faktor pembuktian tentang hutang tersebut. Masalahnya jika disebuah pasar tradisional ada transaksi jual beli daripenjual dan pembeli walaupun dengan volume nominal dibawah Rp. 1.000.000,- (satu tuja rupiah) 
dilaksanakan dengan proses standar pembuktian. Maka pihak pembeli banyak yang mundur karena merasa takut berurusan dengan hukum. Mereka akan membatalkan pembelian tersebut dan akan mencari pedagang lain yang mamu memberi hutang dengan tanpa prosedur / pembuktian seperti pada pedagang sebelumnya.

Menurut Prof. Subektimengenai resiko dalam jual beli dalam KUH Perdata ada tiga peraturan:

a. A.Mengenai barang tertentu (pasal 1460)

b. Mengenai barang yang dijual, menurut berat, jumlah atau ukuran (pasal 1461) dan

c. Mengenai barang-barang yang dijual menurut tumpukan (pasal 1462) (Subekti, 1985: 25).

Barang tertentu seperti disebutkan pasal $1460 \mathrm{KUH}$ Perdata menurut Prof Subekti:

Barang yang pada waktu perjanjian dibuat sudah ada dan ditunjuk oleh pembeli (Subekti, 1985: 25).

Jadi barang itu oleh penjual sudah dilihat dan sudah ditunjuk karena sudah sesuai dengan kehendaknya dan barang tersebut bukan barang yang belang, ada sehingga pihak pembeli mengira - ngira barang tersebut tentang kwalitas dan sebagainya.

Mengenai pasal $1460 \mathrm{KUH}$ perdata tersebut yang menimbulkan beban kepada si pembeli bila terjadi hal-hal yang tidak diinginkan. Jika penyerahan barang tersebut tidak langsung di bawa oleh si pembeli maka bila dalam pengiriman barang itu hancur, maka itu resiko bagi si pembeli. Masalah resiko bagaimana dalam pasal $1460 \mathrm{KUH}$ Perdata dianggap tidak adil karena letak persesuaian kehendak atau kata sepakat terjadi, maka resiko suda ada di pihak pembeli. Untuk itu Mahkamah Agung dalam Surat Edaran No. 3 Tahun 1963 telah menyatakan pasal tersebut tidak berlaku lagi.

Dengan demikian dapat disimpulkan mengenai resiko tentang barang yang dijadikan obyek pembelian selama barang tersebut belum di lever atau diserahkan oleh penjual kepada si pembeli, maka resiko tentang barang masi ada pada penjual yang dianggap masih merupakan pemilik sah barang tersebut sampai dengan barang tersebut di serahkan secara 
yuridis pada pembeli maka selanjutnya resiko ada pada pihak pembeli.

Menurut ketentuan-ketentuan pasal 1460 dan 1462 KUH Perdata Resiko atas barang-barang yang dijual menurut berat, jumlah atau ukuran diletakkan pada pundak penjual, sehingga barang-barang itu telah ditimbang, dihitung, dan diukur sedangkan resiko atas barang-barang yang dijual menurut tumpukan diletakkan pada pembeli. (Subekti, 1985: 27).

Ada perbedaan pasal 1461 dengan pasal 1462 KUH Perdata dikarenakan barang yang harus ditimbang terlebih dahulu hingga ketemu beratnya serta barang yang harus diukur ataupun dihitung terlebih dahulu ketemu hitungannya lebih dahulu. Setelah mengetahui semuanya dan diserahkan walaupun belum dibayar sudah menjadi resiko pembeli. Demikian juga barang yang dibeli berdasar tumpukan dapat dikatakan sudah menjadi resiko pembeli, dikarenakan sudah dipisahkan dengan barang-barang lainnya. Sudah barang tentu jika pembeli sudah menunjuk barang tersebut untuk dibelinya walaupun harganya belum dibayarkan.

Pada pasal 1320 KUH Perdata tidak menganut sistem tertutup tetapi menganut sistem terbuka, sehingga kesepakatan apapun yang dibuat selama tidak melanggar Undang - Undang maka merupakan Undang - Undang bagi pembuatnya, itu termaktub dalam pasal $1338 \mathrm{KUH}$ Perdata. Apabila dunyatakan juga kesepakatan - kesepakatan tersebut harus didasari dengan itikad baik bagi para pembuatnya. Jadi tidak boleh kesepakatan itu dibuat dengan rencana akan diadakan penipuan ataupun niat tidak membayar hutang-hutang yang dibuatnya.

Namun didalam pasal 1321 KUH Perdata disebutkan bahwa jika kesepakatan yang diberikan karena kekhilafan atau diperolrhnya dengan paksaan ataupun penipuan maka kesepakatan itu tidak sah. Paksaan yang dilakukan terhadap orang yang membuat persetujuan baik itu pihak penjual maupun pihak pembeli merupakan alasan untuk membatalkan suatu persetujuan. Paksaan itu juga dapat terjadi bila perbuatan perbuatan salah satu pihak itu dirasakanmenakutkan sehingga salah satu pihak merasa ketakutan bila tidak menyetujui persetujuan tersebut. Perbuatan yang dirasakan menakutkan bisa jadi dilakukan oleh pihak ketiga agar salah satu pihak yang menjadi sasaran itu membuat persetujuan tentang jual beli tersebut. 
Paksaan - paksaan demikian tersebut menimbulkan bataknya suatu persetujuan yang dibuat oleh keduanya. Bahkan lebih jauh lagi bila paksaan tersebut dilakukan kepada keluarganya dengan alasan apapun juga, yang menimbulkan rasa takut bagi salah satu atau seluruh keluarganya maka persetujuan yang telah dibuat / dikarenakan ada rasa ketakutan bagi keluarganya maka persetujuan tersebut batal demi hukum.

\section{Wanprestasi}

Dalam utang piutang akibat jual beli tersebut yang dilaksanakan dengan hanya memakai catatam diatas kertas tanpa tangan tangan dari pihak yang berhutang maupun tanpa saksi adalah wanprestasi bila si berutang tidak melakukan kewajibannya yaitu membayar hutangnya Istilah wanprestasi tidak dilihat dari formilnya melainkan letak wansprestasi dilihat dari hakekatnya yaitu salah satu satu pihak dalam perjanjian tersebut baik itu secara tertulis maupun secara lesan tidak melaksanakan kewajibannya. Dengan demikian salah satu pihak lalai untuk melakukan pembayaran baik itu dilakukan dengan sengaja maupun tidak dilakukan dengan sengaja.

Menurut Kartini Mulyadi dan Gunawan Widjaja Wanprestasi adalaha:

Istilah yang menunjukkan pada ketiadalaksanaan prestasi oleh debitor. Bentuk ketiadalaksanaan ini dapat terwujud dalam bentuk yaitu:

1. Debitor sama sekali tidak melaksanakan kewajibannya.

2. Debitor tidak melaksanakan kewajibannya sebagaimana mestinya / melaksanakan kewajibannya tetapi tidak sebagaimana mestinya.

3. Debitor tidak melaksanakankewajibannya pada waktun.

4. Debitor melaksanakan sesuatu yang tidak diperbolehkan (Kartini Mulyadi dan Gunawan, 2002: 69).

Selanjutnya pada pasal 1236 KUH Perdata disebutkan bahwa:

Debitor adalah berkewajiban memberikan ganti biaya, rugi dan bunga kepada kreditor, apabila telah membawa dirinya dalam keadaan tidak mampu untuk menyerahkan keberatannya atau telah tidak merawatnya sepatutnya guna menyelamatkannya. 


\section{Pada Pasal 1239}

Tiap - tiap perikatan untuk berbuat sesuatu atau untuk tidak berbuat sesuatu, apabila kreditor tidak memenuhi kewajibannya, mendapatkan penyelesaiannya dalam kewajiban memberikan penggantian biaya, rugi dan bunga.

Jika dilihat dari aturan diatas maka keterlibatan pembayaran atau pun tidak ditepati waktu pembayarannya oleh pihak yang berutang dapatlah di tuntut ganti rugi berupa pembayaran bunga. Namun pada prakteknya di pasar tradisional pihak penjual hanya menuntut pembayaran pokoknya saja, karena jika dituntut pembayaran ganti rugi dengan pembayaran pokok dan bunga maka bisa jadi pihak penjual dianggap melaksanakan praktek rentenir. Bagi penjual masalah rentenir masih banyak yang merasa tabu untuk mendengarnya, apabila dicap sebagai rentenir. Itu dianggap sebai hal yang memalukan, walaupun Undang-Undang memperbolehkannya. Selain itu nominal jual belinya juga dianggap tidak terlalu besar karena biasanya dalam jumlah dibawah Rp. 1.000.000 (satu juta rupiah).

Pihak penjual hanya mengharapkan pembayaran pokok hutangnya saja tanpa pembayaran bunga, walaupun hutang itu dibayar dalam waktu yang tidak biasanya artinya bisa jadi dibayar dalam waktu 1 bulan, 2 bulan, 3 bulan atau bahkan lebih dari itu. Biasanya pihak penjual melakukan tagihan secara terus menerus pada si berutang agar cepat menyelesaikannya meskipun kadang juga menambah biaya operasional. Jika beruntung lokasi rumahnya agak jauh, namun pihak penjual tidak mengenakan bunga. Dibayar pokok hutangnya saja itu sudah cukup menggembirakan bagi penjual.

\section{Penyelesaian Hutang Piutang}

Dengan demikian bila hutangnya tidak terbayar oleh si pembeli, maka biasanya pihak penjual tidak pernah menjadikan hutang piutang tersebut, sampai dengan menjadi masalah hukum, yang pada akhirnya berujung di pengadilan. Hal tersebut dapat dimaklumi dikarenakan jumlah hutang tersebut dianggap sangat kecil, jika harus berujung ke pengadilan selian itu jika sedikt-sedikit berujung ke masalah hukum 
maka calon pembeli yang mungkin berharap bisa berhutang akan menjauh dikarenakan proses jual beli tersebut tidak lazim, dikalaupun di pasar tradisional, yang menekankan kepercayaan antara penjual dan pembeli, selain itu dipasar tradisional sangatlah awam tentang jual beli. Yang harus memenuhi unsur - unsur pasal $1320 \mathrm{KUH}$ perdata mereka hanya menekankan pada lazimnya atau secara adat bahkan mereka lebih mengerti hukum agama dari pada hukum nasional. Hal ini seperti barang siapa yang membeli sudah barang tentu harus membayar dan jika siapapun yang berhutang juga juga pasti harus dibayar bila tidak dibayar mereka akan berdosa dan kelamaan bisa dikucilkan oleh para pedagang dan jelas tidak akan diberi pembelian dengan hutang lagi, bila sering tidak mebayar hutangnya. Jadi unsur kepercayaan sangat urgen dalam proses jual beli dengan sistem hutang piutang tersebut.

Unsur menuntut kerugian yang ditanggung oleh penjual tersebut tidaklah diselesaikan secara hukum melainkan dengan proses kekeluargaan. Tentunya penyelesaian sengketa tersebut tidak menekankan pada kerugian yang semakin bertambah seperti berupa bunga atau transport yang harus bolak balik namun cukup dengan pembayaran hutang, pokoknya dan mungkin ditambahkan dengan perkataan permohonan maaf dikarenakan beberapa hal yang menjadikan hutang tersebut macet.

Berati jual beli dengan proses hutang piutang tersebut belum memenuhi unsur kontrak sebagaimana disebutkan oleh Dr. Muhammad Syaifuddin.

1. Kontrak menjamin harapkan yang saling diperjanjikan dinatara para pihak akan terpenuhi, atau akan tetap ada kompensasi yang dibayarkan apabila terjadi wanprestasi.

2. Kontrak mempermudah rencana transaksi bisnis masa depan dari berbagai kemungkinan yang merugikan.

3. Kontrak menetapkan standar pelaksanaan dan tanggung jawab para pihak.

4. Kontrak memungkinkan pengalokasian resiko bisnis secara lebih tepat (meminimalisasi resiko bisnis para pihak)

5. Kontrak menyediakan barang, penyelesaian sengketa bagi para pihak (Muhamad Syaifuddin, 2012: 52 ).

Selanjutnya menurut Yudya Hernoko fungsi Kontrak adalah:

1. Kontrak sebagai wadah hukum bagi para pihak dalam 
menuangkan hak dan kewajiban masing - masing (bertukar konsesi dan kepentingan)

2. Kontrak sebagai bingkai aturan main.

3. Kontrak sebagai alat bukti adanya hubungan hukum.

4. Kontrak memberikan (menjamin) kepastian hukum.

5. Kontrak menjunjung iklim bisnis yang kondusif (Muhamad Syaifuddin, 2012: 52).

Dengan demikian proses hutang dalam bingkai jual beli di pasar tradisional yang nominalnya di bawah Rp. 1.000.000,- (satu juta rupiah) sulit untuk dibingkai dalam hukum kontrak yang dilakukan secara tertulis apalagi kalau dilakukan secara notariil. Perjanjian sederhana antara penjual dan pembeli dilakukan secara lesan dan dicatat secara sederhana lebih menekankan unsur kepercayaan dari pada unsur pembuktiannya.

Hal ini menyebabkan kesulitan bagi pihak penjual untuk mengembalikan piutang tersebut bila dikemudian hari hutang tersebut macet. Hal ini terjadi di pasar tradisional yang menekankan unsur kepercayaan dan proses cepat karena pihak penjual segera melayani pembeli yang lain.

Penyelesaian hutang yang macet dilakukan dengan cara mengintensifkan penagihan dan pihak penjual biasanya menerima jika hutang tersebut dibayar dengan mencicil, walaupun dicicil itu pokok hutangnya saja. Dalam proses penagihan biasanya pihak penjual tidak memberi beban apapun seperti bunga atau beban operasional seperti transport. Hal ini dianggap sebagai resiko jual beli di pasar tradisional. Inipun biasanya tidak lebih dari sekitar $10 \%$ dari seluruh hutang, itupun sudah masuk perhitungan resiko bagi penjual. Proses hutang yang menekankan ke unsur hukum akan melibatkan calon-calon pembeli yang walaupun secara hutang akan menghindar karena merasa ketakuta. Oleh karena itu di pasar tradisonal akan banyak menekan unsur kepercayaan walaupun faktor resiko itu ada. Itulah yang membedakan transaski jual beli secara hutang piutang di pasar tradisonal dengan dilain tempat atau pasar modern misalnya.

Hutang piutang walaupun kecil dan dilakukan tanpa kontrak tertulis sebagaimana mestinya, tetaplah utang yang harus dibayar, karena pada awalnya sudah merupakan persesuaian kehendak antara pihak yang 
berhutang dan berpiutang.

Kesepakatan diantara keduanya sudah menjadi hukum positif dan harus menjadi Undang - Undang bagi para pembuatnya. Masalahnya hutang piutang itu dilakukan dibawah tangan dan tidak tertulis sehingga bila terhutang tidak menepati janjinya untuk membayar maka bila di bawa kehadapan meja hijau pembuktiannya tidak begitu kuat. Hukum acara perdata kita masih menganut pembuktian saksi dan tertulis bila terjadi masalah dan berakhir di meja hijau.

Jadi pada hakekatnya semoga masalah hutang piutang berakhir pada itikad baik bagi para pembuatnya. Itikat baik tersebut yang mendasari persesuaian kehendak untuk mengawali perbuatan hukum dan mengakhirinya dengan penyelesaian yang baik sesuai dengan norma hukum.

Dengan demikian hutang piutang yang terjadi antara penjual dan pembeli didalam pasar tradisional tersebut tidak bisa diselesaikan secara hukum murni. Hal ini mengingat mereka masih membutuhkan pelanggan untuk memutar roda penjualannya. Sementara kalau dipaksaan menyelesaikan secara hukum para pelanggan akan berhitung ulang untuk meneruskan jual beli dengan sistem hutang di pedagang tersebut, dikarenakan ada ketakutan bila suatu saat ketika macet bisa jadi juga akan diperkarakan.

Oleh kerana itu pedagang pedagang yang memutar roda penjualannya dengan sistem hutang tersebut akan menekankan pelanggannya dengan sistem kepercayaan. Sejak awal terjadinya transasksi jual beli biasanya pembeli tidak langsung hutang begitu saja tetapi membina kepercayaan dengan bayar kontan dulu secara teratur, hingga pada suatu saat pembeliannya mulai banyak transaksi jual beli maka disaat seperti ini banyak transaski jual beli, maka disaat seperti ini biasanya pedagang mulai berhitung apabila pembeli ini dapat dipercaya atau tidak. Jika dipercaya maka terjadilah awal transaksi hutang piutang namun bila tidak dipercaya makan terjadi transaski sebagaimana biasanya.

Penentuan kepercayaan ini yang kadang sering sulit diterka keberhasilannya. Jika pedagang tidak hati - hari betul maka akan terjadi hutang yang macet, dan akan menimbulkan kerugian. Jadi bila dimasukkan dalam syarat-syarat perjanjian maka yang terpenuhi hanya syarat sepakat, untuk syarat-syarat lainnya masih membutuhkan 
pendalaman lebih lanjut mengingat hutang piutang tersebut hanya dicatat oleh penjual saja. Untuk itu perlu pembinaan hukum yang lebih praktis agar proses hutang piutang tersebut tetap berjalan namun dengan tidak merugikan pedagang tertentu. 


\section{DAFTAR PUSTAKA}

Kartini Mulyadi dan Gunawan Widjaja, 2002, Perikatan Pada Umumnya, Jogja: PT.Raja Grafindo Persada.

Muhammad Syaifuddin, 2012, Hukum Kontrak, Bandung: Mandar Jaya.

Peter Mahmud Marzuki, 2008, Pengantar Ilmu Hukum, Jakarta: Prenada Media Group

Subekti. 1985, Aneka Perjanjian, Bandung: Alumni. , 1982, Pokok-pokok Hukum Perdata, Jakarta: Intermasa.

Suharnoko, 2004, Hukum Perjanjian , Jakarta: Prenada Media Group.

Undang-undang Dasar Republik Indonesia 1945

R.Subekti dan R. Tjitrosudibio, 2001, Kitab Undang-Undang Hukum Perdata, Jakarta: Pradnya Paramita. 